Article

\title{
Extrusion and Characterization of High Si/Al Ratio ZSM-5 Using Silica Binder
}

\author{
Ana Almeida ${ }^{1}$, Rui P. P. L. Ribeiro ${ }^{2} \mathbb{D}$, José P. B. Mota $^{2}$ and Carlos Grande ${ }^{1, *(1)}$ \\ 1 SINTEF Industry, Forskningsveien 1, 0373 Oslo, Norway; Ana.Almeida@theOGTC.com \\ 2 LAQV-REQUIMTE, Department of Chemistry, Faculty of Science and Technology, Universidade Nova de \\ Lisboa, 2829-516 Caparica, Portugal; rpp.ribeiro@fct.unl.pt (R.P.P.L.R.); pmota@fct.unl.pt (J.P.B.M.) \\ * Correspondence: carlos.grande@sintef.no; Tel.: +47-93207532
}

Received: 7 February 2020; Accepted: 3 March 2020; Published: 5 March 2020

\begin{abstract}
Biogas upgrading is a key operation for transforming raw biogas into valuable biomethane that can be used as fuel or transported through pipelines. Pressure swing adsorption (PSA) is one possible technique that can be used for upgrading. ZSM-5 with high silica/aluminum ( $\mathrm{Si} / \mathrm{Al}$ ) ratio has a reasonable $\mathrm{CO}_{2} / \mathrm{CH}_{4}$ selectivity and an almost linear $\mathrm{CO}_{2}$ adsorption isotherm, which can reduce power consumption. Extrusion of zeolites uses Al-based binders which can result in a denaturation and in a decrease of $\mathrm{Si} / \mathrm{Al}$ ratio, promoting a steeper $\mathrm{CO}_{2}$ isotherm and also impacting the water adsorption. In this work, we have extruded a ZSM-5 (with a Si/Al = 200) using only silica-based binder. Different samples were obtained using different extrusion paste compositions and operating conditions and their textural properties characterized. The mechanical strength of the samples as well as the $\mathrm{CO}_{2}, \mathrm{CH}_{4}$, and $\mathrm{H}_{2} \mathrm{O}$ adsorption equilibrium isotherms at $303-343 \mathrm{~K}$ were measured. Our results show that it is possible to produce extrudates with mechanical resistance comparable to (or higher than) commercial zeolite materials with surface area reductions lower than $10 \%$ and little or no impact on the $\mathrm{CO}_{2} / \mathrm{CH}_{4}$ selectivity.
\end{abstract}

Keywords: zeolite; ZSM-5; adsorption; biogas upgrading; shaping; extrusion

\section{Introduction}

Over the last 50 years, there has been an enormous expansion of the available porous materials. The vast possibilities of surface customization have boosted the research on separation technologies, like membranes and adsorption-based processes [1,2]. However, for new materials, there is a large gap between discovery and its utilization in industrial applications. Such gap lays primarily in having a good knowledge of proper practices for the shaping of powders into millimeter-scale particles [3-7]. The challenge is to have particles with adequate hardness and size to be used in large columns but with minimal changes to their properties as powders. For adsorption processes, particles are in the $\mathrm{mm}$-scale to keep the pressure drop controlled while limiting diffusion effects. Novel applications in moving-bed type of reactors require sub-mm particle diameters [8]. The typical shapes of industrial porous materials are pellets, extrudates, laminates, and monoliths [9].

Several methods can be used for shaping porous materials. The most industrialized technologies are extrusion [4,10-15] and spray drying [16-19]. Many other technologies are at the research and demonstration stages, and the details are not published in many cases since this is the pre-commercial step for a material. Some of the technologies that can find a commercial path in the near future are hydrocolloids [20,21], powder compression [22-24], and casting [25]. Recently, 3D printing is being used for the production of shapes [26-29].

Due to its fast production rate, extrusion is nowadays the technology most employed for shaping porous materials. The term extrusion describes a process involving the movement of a material through 
a confined space using little-to-no solvent. Extrusion started as a technology for shaping metals into pipes and has been extended into polymers, pharmaceuticals, food, etc. In extrusion, the movement of the material can be propelled by a hydraulic medium (piston) or by screws. In order to be extruded, the solid material should have appropriate plastic properties. Since the shear forces in extrusion can be intense, a material without the correct viscosity, for example, can be heated to extreme temperatures, possibly damaging its structure or completely changing its properties.

Solid porous materials are normally mixed into pastes composed of a "binder" (or mixture of binders) that provides mechanical strength and moldability, and a plasticizer that serves as wetting agent and decreases the viscosity of the mixture, forming a plastic composition. Optionally, a dispersant can be added to avoid agglomeration [30-32]. Finding the right combination of the correct ingredients that will produce a successful paste is challenging, and there is currently no theoretical approach for this.

ZSM-5 is a well-known commercial zeolite. It is possible to control its acidity to a great extent by controlling the $\mathrm{Si} / \mathrm{Al}$ ratio. It is known that the adsorption properties of ZSM-5 (and also other zeolites) depend on its Si/Al ratio [33-35]. When shaping zeolites, clays, alumina, and silica are commonly used to provide hardness to the extrudates. Organic additives may also be added, increasing the strength of the extrudate and reducing shape variations during extrusion. Cellulose, methylcellulose, and polyvinyl alcohol (PVA) are the most common organic additives. They also contribute to generate macroporosity in the final shaped particles. Water is the most used plasticizer. After the paste is extruded, it is normally dried to remove the plasticizer and then "fired" to $\sim 750 \mathrm{~K}$ where some chemical reactions (or sintering) take place: methyl siloxane ether transforms into silica [36] and kaolin into metakaolin [32]. The organic additives are burned generating macroporosity.

In the case of using a ZSM-5 with high Si/Al ratio, it is essential that the elements composing the paste do not result in a change of adsorption properties. Carbon dioxide and water adsorption isotherms are very sensible to changes in $\mathrm{Si} / \mathrm{Al}$ ratio and cation substitutions, due to their quadrupole moment and polarity, respectively. In adsorption processes, the adsorption "strength" yielded by the initial slope of the isotherm can result in higher capacity, but it also results in the need for regenerating at a lower pressure increasing power consumption.

In this work, we have extruded high silica ZSM-5 $(\mathrm{Si} / \mathrm{Al}=200)$ with pure silica binders aiming to avoid acidification of the zeolite during the extrusion process. The prepared samples also used an organic binder (PVA) and water as plasticizer. Different paste compositions were used for extrusion, and the resulting samples were characterized in terms of surface area and mechanical strength. The most successful sample was used for measurement of adsorption equilibrium of $\mathrm{CH}_{4}$ and $\mathrm{CO}_{2}$ and $\mathrm{H}_{2} \mathrm{O}$ at 303,323 , and $343 \mathrm{~K}$.

\section{Materials and Methods}

\subsection{Chemicals}

A commercial sample of zeolite ZSM-5 (Clariant, Muttenz, Switzerland) with a Si/Al ratio of 200 was employed as the target porous solid to be shaped. Polyvinyl alcohol (PVA, Aldrich, Schnelldorf, Germany) and colloidal silica (LUDOX®LS, $220 \mathrm{~m}^{2} / \mathrm{g}, 30 \mathrm{wt} \%$, Aldrich, Schnelldorf, Germany) were used as temporary and permanent binders, respectively. Deionized water was employed as plasticizer.

Pure gases employed in the adsorption equilibria measurements were provided by Yara (Oslo, Norway): $\mathrm{CH}_{4}$ (purity $>99.995 \%$ ) and $\mathrm{CO}_{2}$ (purity $>99.9992 \%$ ).

\subsection{ZSM-5 Extrudates Preparation}

ZSM-5 extrudates were made in a Thermo Scientific (Karlsruhe, Germany) HAAKE MiniLab II twin-screw extruder equipped with two co-rotating screws and a $2 \mathrm{~mm}$ diameter dye. The extruder is equipped with a backflow channel and an automatic bypass valve that allow the operator to work with well-defined residence times. The extruder can directly push the sample from the feeder to the dye in a 
normal extrusion process that we denominate here as "open cycle". Another option that the extruder has is that it allows to recirculate the same paste from the end of the extruder to the feed point to obtain better mixing. Operation under the recycling mode is termed here as "closed loop". Extrusion in open and closed cycles were tested. Preliminary experiments with long recirculation times indicated that similar results are obtained for recirculation times over 5 minutes. For this reason, in this work, the extruder was operated with a recirculation time of 5 minutes emulating longer processes.

For extrusion purposes, pastes were prepared containing powdered ZSM-5 zeolite, PVA (temporary binder), colloidal silica (permanent binder), and water as plasticizer. The pastes were prepared by mixing ZSM-5 and PVA powders followed by addition of water and LUDOX®in appropriate amounts. Several paste compositions were prepared and extruded to evaluate the influence of the zeolite/binder ratio on the paste properties and obtained extrudates. The composition of the samples successfully extruded are detailed on Table 1.

Following extrusion, the samples were air-dried at constant temperature $(298 \mathrm{~K})$ for at least 24 hours. Subsequently, the extrudates underwent a firing stage, which consisted of gradually heating the samples to $773 \mathrm{~K}$ for 12 hours to remove the plasticizer and temporary binder, generating macroporosity within the extruded sample.

\subsection{Characterization of ZSM-5 Extrudates}

The samples of ZSM- 5 extrudates prepared were thoroughly characterized. All samples underwent compression tests, scanning electron microscopy (SEM), and $\mathrm{N}_{2}$ adsorption at $77 \mathrm{~K}$ for surface area assessment. Furthermore, the best sample was selected for measurement of $\mathrm{CH}_{4}, \mathrm{CO}_{2}$, and $\mathrm{H}_{2} \mathrm{O}$ adsorption equilibrium isotherms up to 1 bar at 303, 323, and $343 \mathrm{~K}$.

The mechanical stability and stiffness of the prepared extrudates were evaluated through compression/crushing tests. For this purpose, a Zwick/Roell Z250 universal test machine equipped with a $500 \mathrm{~N}$ load cell was employed. For each assay, a sample was placed on the center of the lower compression plate, which was lifted against the upper plate at a rate of $0.5 \mathrm{~mm} / \mathrm{min}$. The assay was performed three times for each sample using a single pellet each time (diameter $\sim 2 \mathrm{~mm}$, length $\sim 5 \mathrm{~mm}$ ). TestXpert II software was used to record the stress-strain curve, i.e., applied force $(\mathrm{N})$ as a function of the sample deformation ( $\mathrm{mm}$ ).

Scanning electron microscopy (SEM) was performed in a Zeiss Auriga CrossBeam FIB/SEM workstation available at Cenimat/i3N (FCT-NOVA). SEM images were taken using $5.0 \mathrm{kV}$ acceleration voltage.

$\mathrm{N}_{2}$ adsorption at $77 \mathrm{~K}$ was determined in a BELSORP-mini II instrument. The ZSM- 5 extrudates samples were externally degassed at $423 \mathrm{~K}$ overnight followed by 2 hours degassing in the unit at $423 \mathrm{~K}$ under vacuum. The obtained data were employed to determine the BET surface area and specific pore volume of the samples.

\subsection{Adsorption Equilibrium of $\mathrm{CO}_{2}, \mathrm{CH}_{4}$, and $\mathrm{H}_{2} \mathrm{O}$}

$\mathrm{CO}_{2}, \mathrm{CH}_{4}$, and $\mathrm{H}_{2} \mathrm{O}$ pure component adsorption equilibrium isotherms were determined at 303 , 323 , and $343 \mathrm{~K}$. Data were collected using a Belsorp-MAX volumetric apparatus: in the $0-1$ bar pressure range for $\mathrm{CH}_{4}$ and $\mathrm{CO}_{2}$ and up to $4 \mathrm{kPa}$ for water vapor. The degassing procedure was the same employed prior to the $\mathrm{N}_{2}$ isotherms. Both adsorption and desorption data were measured to confirm the reversibility of the process and check for hysteresis.

\section{Results}

\subsection{Characterization of ZSM-5 Extrudates}

In this work, 21 samples were prepared in order to study the effect of the different components in the production of high Si/Al ZSM-5 extrudates. The paste preparation showed that the content of additives greatly affects the consistency of the extrusion paste and its ability to undergo the extrusion 
process. Some of the pastes could not be extruded at all, and some others were not characterized because their shape indicated that the extrusion was not successful. In this publication, only the successfully extruded ZSM-5 are presented. Extrusion using a wide range of paste compositions consequently resulted in extrudates with different features. Figure 1 shows the binder composition of the ZSM-5 extrusion pastes and the effect of this composition on extrudate shape and appearance.

The particle density $\left(\rho_{p}\right)$ of each extruded sample was calculated by measurement of the mass $(w)$, length $(l)$, and diameter $(d)$ of each pellet. To reduce error in the measurements, the corners were flattened with a scalpel. Based on the measurements, the volume of each pellet $\left(V=\pi \frac{d^{2}}{4} \times l\right)$ was used to calculate the particle density via $\rho_{p}=\frac{w}{V}$.

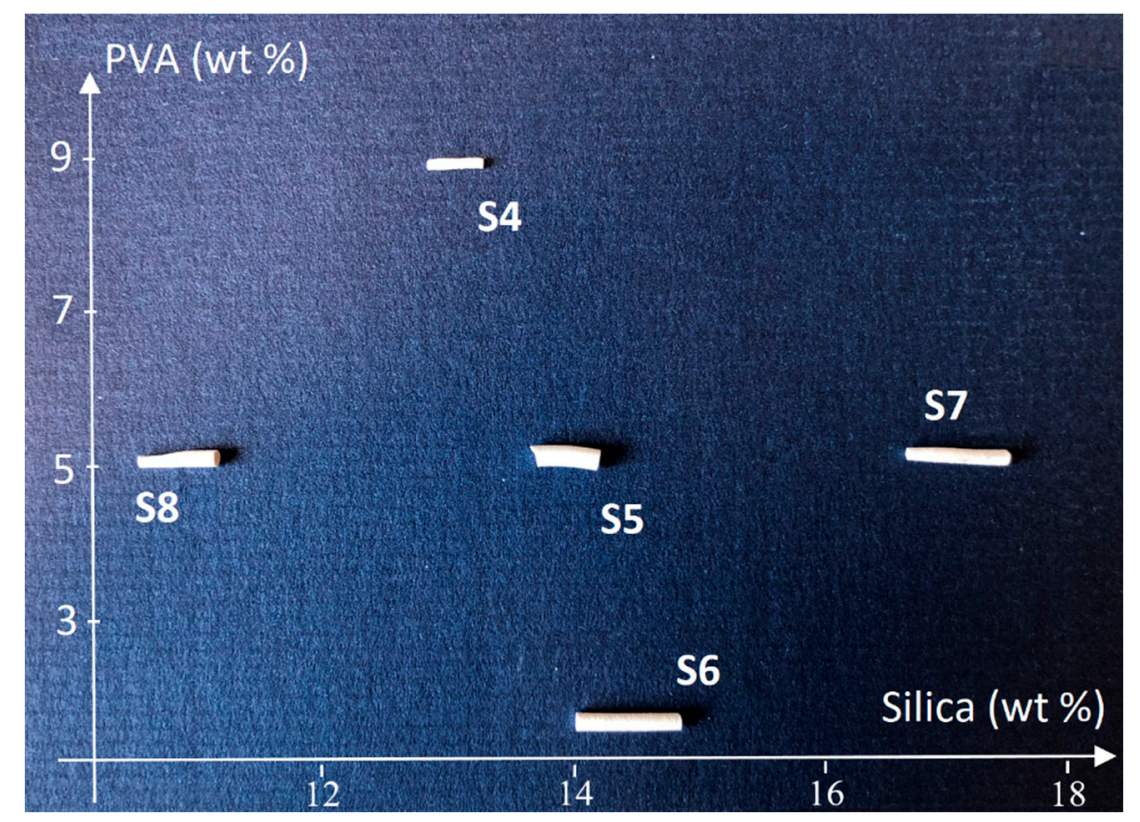

Figure 1. Effect of binder composition on the morphology of ZSM-5 extrudates.

Table 1 summarizes the density results obtained on the effect of paste composition. Sample 4 has high PVA content, and the extruded paste was very viscous and flexible. After thermal treatment, this resulted in uneven extrudates with irregular diameters and low mechanical resistance. Extrusion in closed cycles slightly improved consistency, however, these samples were not selected for further characterization. Sample 5, with intermediate PVA content, resulted in consistent extrudates. Extrusion in closed cycles produced stronger extrudates than in open cycles with shorter extrusion times. Sample 6 has low PVA content and produced extrudates with regular shape and diameter. A sample with the same composition was tested under closed cycles and the results were not satisfactory.

Table 1. Composition of ZSM-5-based extrusion pastes and extrudates density.

\begin{tabular}{cccccc}
\hline Sample & Preparation & $\begin{array}{c}\text { ZSM-5 } \\
(\mathbf{w t} \%)\end{array}$ & $\begin{array}{c}\text { PVA } \\
\mathbf{( w t ~ \% )}\end{array}$ & $\begin{array}{c}\text { Silica } \\
\mathbf{( w t ~ \% )}\end{array}$ & $\begin{array}{c}\text { Density } \\
\mathbf{( g / \mathbf { c m } ^ { 3 } )}\end{array}$ \\
\hline 4 & Open cycle & 77.4 & 9.0 & 13.6 & N.A. \\
5 & Closed cycle & 81.0 & 5.0 & 14.0 & 1.17 \\
6 & Open cycle & 83.7 & 2.0 & 14.3 & 1.03 \\
7 & Closed cycle & 78.0 & 5.0 & 17.0 & 0.98 \\
8 & Closed cycle & 84.0 & 5.0 & 11.0 & 1.14 \\
16 & Closed cycle & 80.0 & 5.0 & 15.0 & 1.13 \\
\hline
\end{tabular}

Samples 7 and 16, with high silica content, resulted in extrudates with a very irregular surface and slight diameter variations. Closed-cycle extrusion resulted in higher viscosity and better surface 
uniformity. A density of $1.13 \mathrm{~g} / \mathrm{cm}^{3}$ was obtained with $15 \%$ silica content in the paste and $0.98 \mathrm{~g} / \mathrm{cm}^{3}$ with $17 \%$, indicating that the increase over a certain level does not improve the properties of the extrudate. Sample 8 has low silica content and resulted in regularly shaped extrudates. Extrusion in closed cycles improved surface smoothness and increased viscosity causing greater diameter variations.

In order to select samples for further testing, there are two main parameters that should be observed: the density and the surface rugosity. We have highlighted the importance of the density in the sample preparation because if the shaping technique produces samples with low densities, larger columns will be required to pack a similar weight of material. Moreover, if the samples present a very irregular surface, when they are packed, they will generate dust that can increase the pressure drop along the columns and may ultimately damage other equipment like valves, etc.

\subsubsection{Compression Tests}

The mechanical stability of the extrudates was assessed by subjecting the samples to compression/ crushing tests. In these assays, a piston applies a force that increases as the sample is compressed. At the precise moment that the extrudate breaks, there is a sudden drop in the exerted force. The value recorded prior to this decrease is reported as the crushing force or crushing strength of the material. Figure 2 shows a comparison of the results obtained for two extrudates of the same batch and, also, the crushing force required to break an extrudate of commercial $4 \mathrm{~A}$ zeolite [9]. The obtained results clearly show that despite the variability between pellets of the same batch, the extruded ZSM-5 pellets have good mechanical properties comparable to (or even higher than) other commercially available zeolites.

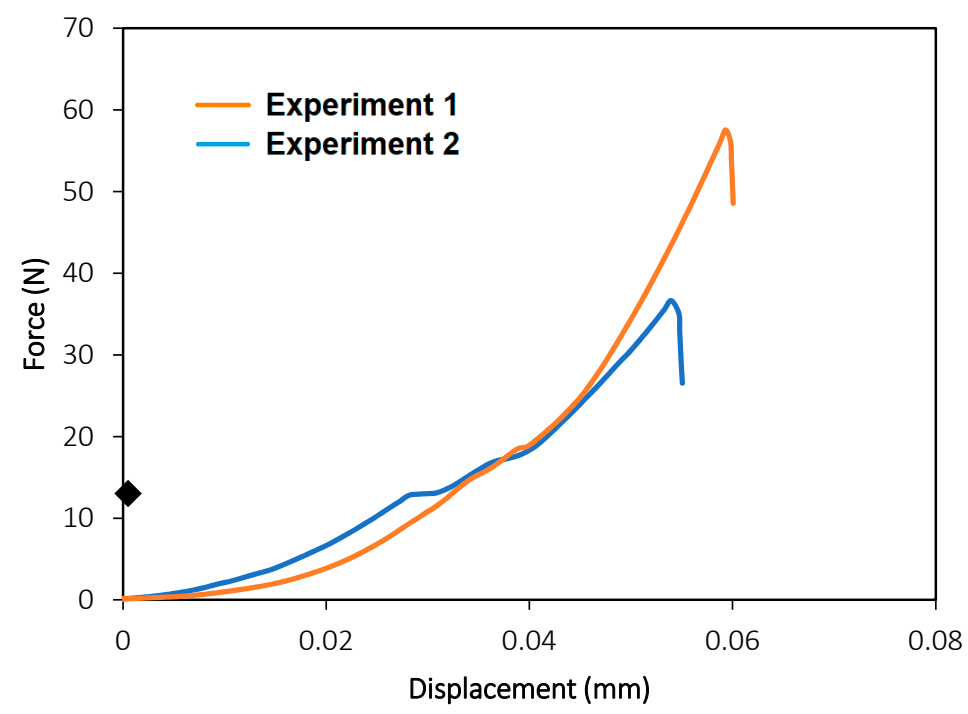

Figure 2. Results of the compression test for two pellets of the same ZSM-5 extrudate sample. (The solid symbol represents the crushing force for a commercial $4 \mathrm{~A}$ zeolite extrudate, reported for comparison [9]).

Figure 3 shows the averaged crushing force as a function of the silica content in the extruded paste (PVA is removed during the post-extrusion thermal treatment). The reported average was taken over three different assays performed for each sample. The results suggest that a correlation between silica content and hardness in ZSM- 5 extrudates exists, although higher amounts of silica are detrimental to the mechanical resistance of the material. This may be explained by the irregular surfaces and diameter variations observed in samples with higher silica content. In those cases (higher amount of silica), the viscosity of the paste increases resulting in a higher pressure inside the extruder. When the paste exits through the die, there is a sudden decompression that results in a solid expansion and in a rough surface. Such decompression clearly affects the mechanical properties. 


\subsubsection{Scanning Electron Microscopy (SEM) Imaging}

The morphology of the ZSM-5 extrudates and the starting ZSM-5 powder were analyzed by SEM imaging. Figure $4 a-c$ show images of the surfaces of the extrudates with their average diameters and without visible cracks at the surface. Some surface rugosity can be observed in sample 7 and, to a lesser extent, in sample 8 . Sample 5 has a very smooth surface, which is a very positive aspect of this sample. SEM imaging showed that although the same die, with $2 \mathrm{~mm}$ diameter, was used in all the extrusions, the final diameter of the extrudates were variable for each batch. Figure $4 a-c$ show that the extrudates can present diameters of $2.0 \mathrm{~mm}$ (sample 5), $1.76 \mathrm{~mm}$ (sample 8), and $1.31 \mathrm{~mm}$ (sample 7). In Figure 4c, it is possible to observe a flat area in one of the sides of the ZSM-5 extrudate. This occurred as the material was placed on a flat surface to dry following extrusion. The materials that deform after extrusion and present an extensive degree of shrinkage are not optimal in their composition. Figure $4 \mathrm{~d}-\mathrm{f}$ presents the SEM images obtained for the extrudates (samples 7 and 8 and the zeolite powder; the SEM images demonstrate that the material underwent extrusion without suffering deformation. The crystal morphology remains apparently unchanged, although a tighter crystal packing and the predominance of smaller and more homogenous structures in the extrudate are observed.

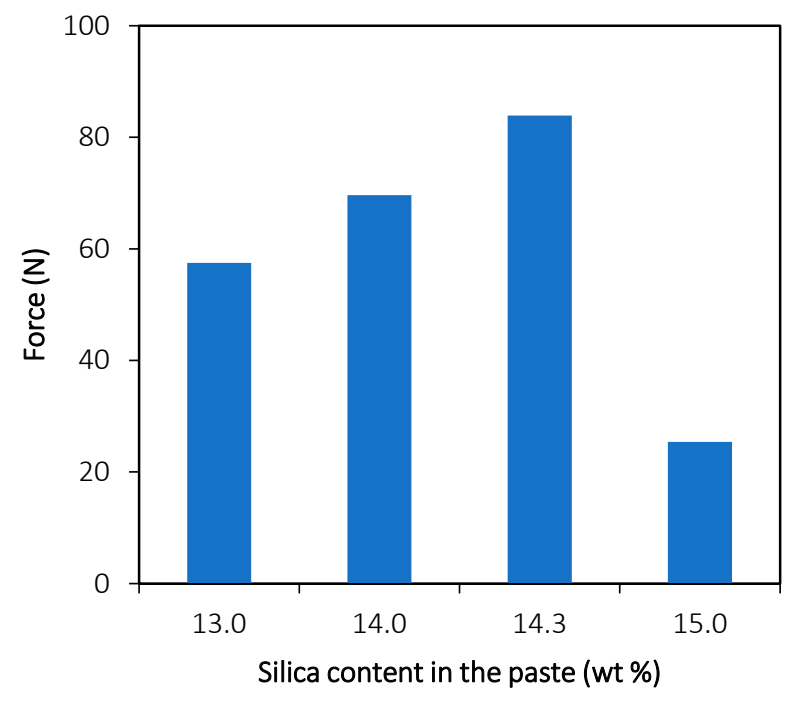

Figure 3. Maximum force applied on ZSM-5 extrudates versus silica content in the extruded paste.

\subsubsection{Nitrogen Adsorption at $77 \mathrm{~K}$}

The $\mathrm{N}_{2}$ adsorption isotherms obtained at $77 \mathrm{~K}$ showed type I behavior indicative of microporous samples with pore filling at high relative pressures. The $\mathrm{N}_{2}$ adsorption isotherms obtained at $77 \mathrm{~K}$ for the pristine powder and extrudates in sample 5 are shown in Figure 5a. The BET surface area was determined from the experimental data and the results obtained for the various silica content on the extrudates after PVA removal through a firing procedure is displayed in Figure 6.

Table 2 presents a comparison between the textural results obtained for sample 5 and the values measured in the ZSM-5 powder. The BET surface area of the zeolite extrudates decreased between $7 \%$ and $11 \%$ in relation to the original ZSM- 5 BET surface area. The observation of a decrease in the available surface area was expected due to the presence of silica binder in the extrudates. Despite some dispersion in the results, there seems to be an approximately linear correlation between the surface area and the silica content in the extrudates, as shown in Figure 6. Assuming that all PVA content is removed from the final extrudates and that $\mathrm{SiO}_{2}$ has a surface area of $220 \mathrm{~m}^{2} / \mathrm{g}$, the theoretical BET that should be obtained for a solid adsorbent composed by $\mathrm{ZSM}-5$ and $\mathrm{SiO}_{2}$, if no detrimental effects in the surface/pore occur, can be calculated. This theoretical line is also shown in Figure 6 and compared with the experimental values obtained as a function of the silica content in the extrudates (assuming 
no remaining PVA). It can be seen that the obtained results are only slightly lower than the expected results when considering the surface area originally reported for the $\mathrm{SiO}_{2}(\mathrm{LUDOX} 囚)$ employed in this study.

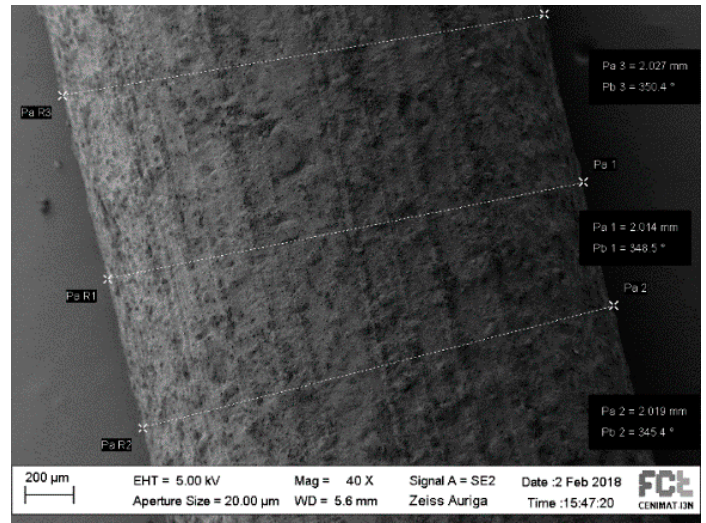

(a)

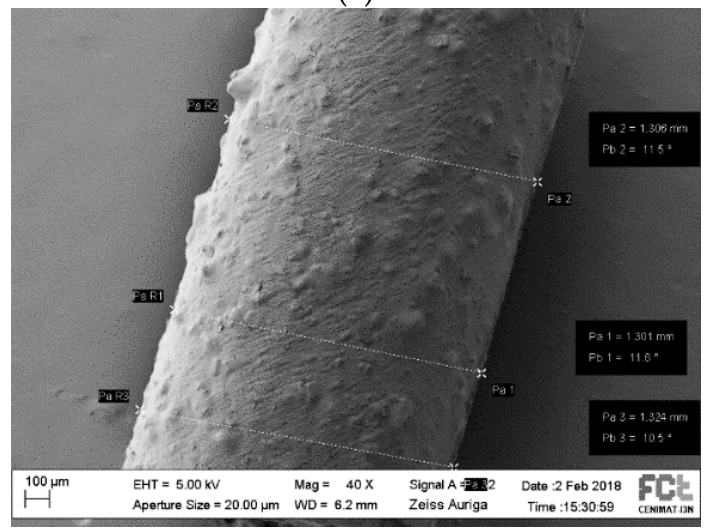

(b)

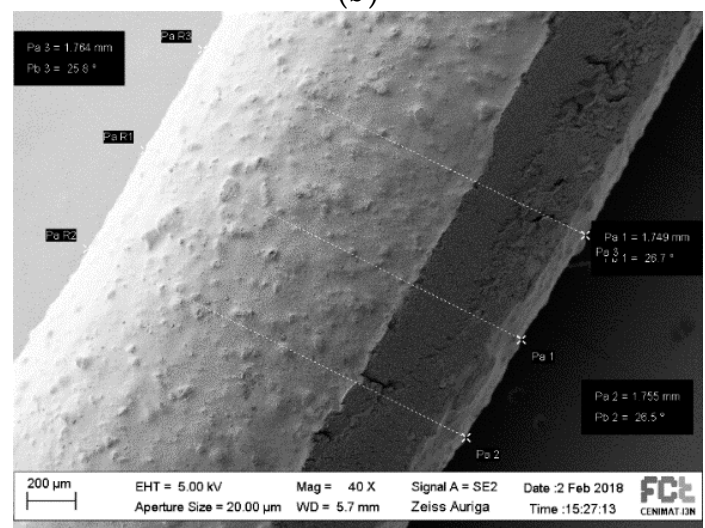

(c)

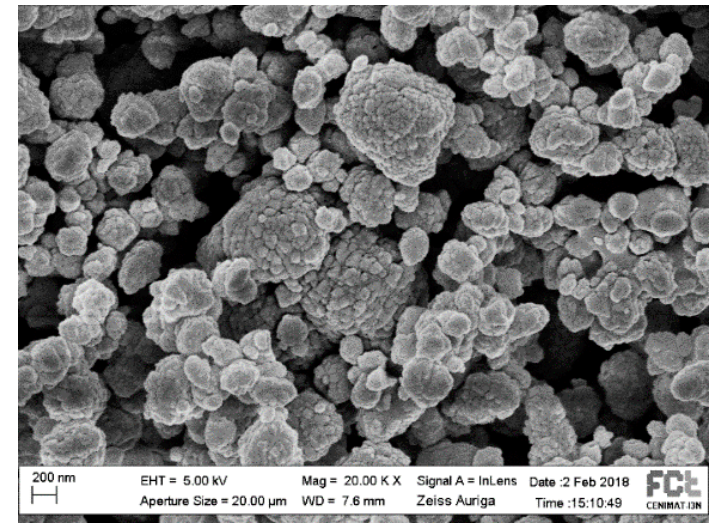

(d)

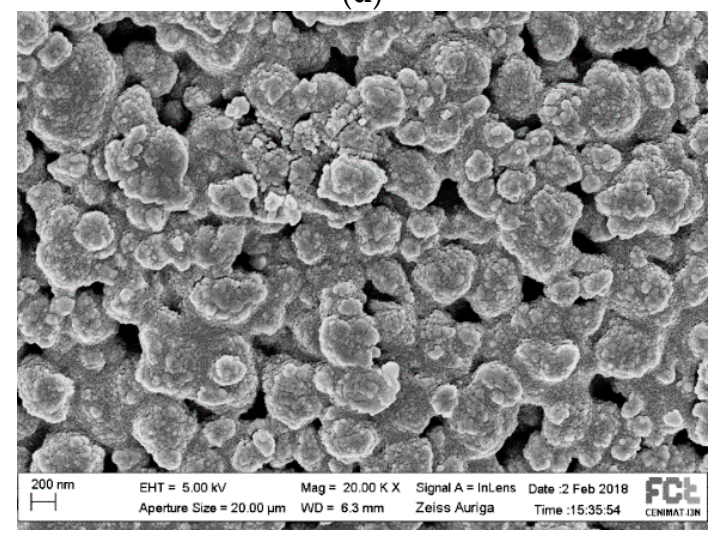

(e)

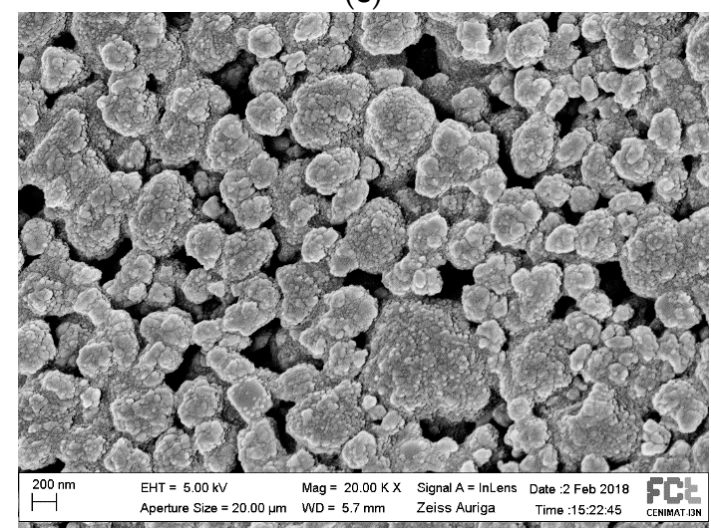

(f)

Figure 4. SEM images of the ZSM-5 extrudates at 40× magnification: (a) sample 5, (b) sample 7, and (c) sample 8. SEM images of: (d) the ZSM-5 powder and extrudates of (e) samples 7 and (f) 8 at $20,000 \times$ magnification.

Table 2. Textural results for best formulation compositions.

\begin{tabular}{ccc}
\hline ZSM-5 Sample & A $_{\text {BET }}\left(\mathrm{m}^{2} / \mathbf{g}\right)$ & Micropore Volume $\left(\mathrm{cm}^{3} / \mathrm{g}\right)$ \\
\hline Powder & 341 & 0.305 \\
Extrudates (Sample 5) & 318 & 0.260 \\
\hline
\end{tabular}




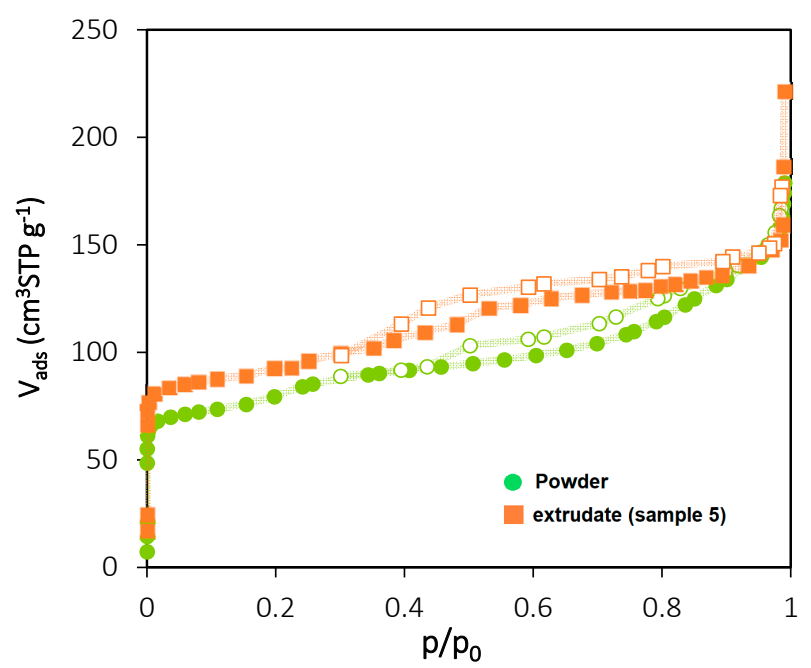

Figure 5. $\mathrm{N}_{2}$ adsorption isotherms at $77 \mathrm{~K}$ for ZSM-5 pristine powder (घ) and extrudate sample $5(\bullet)$. The filled and empty symbols denote adsorption and desorption data, respectively.

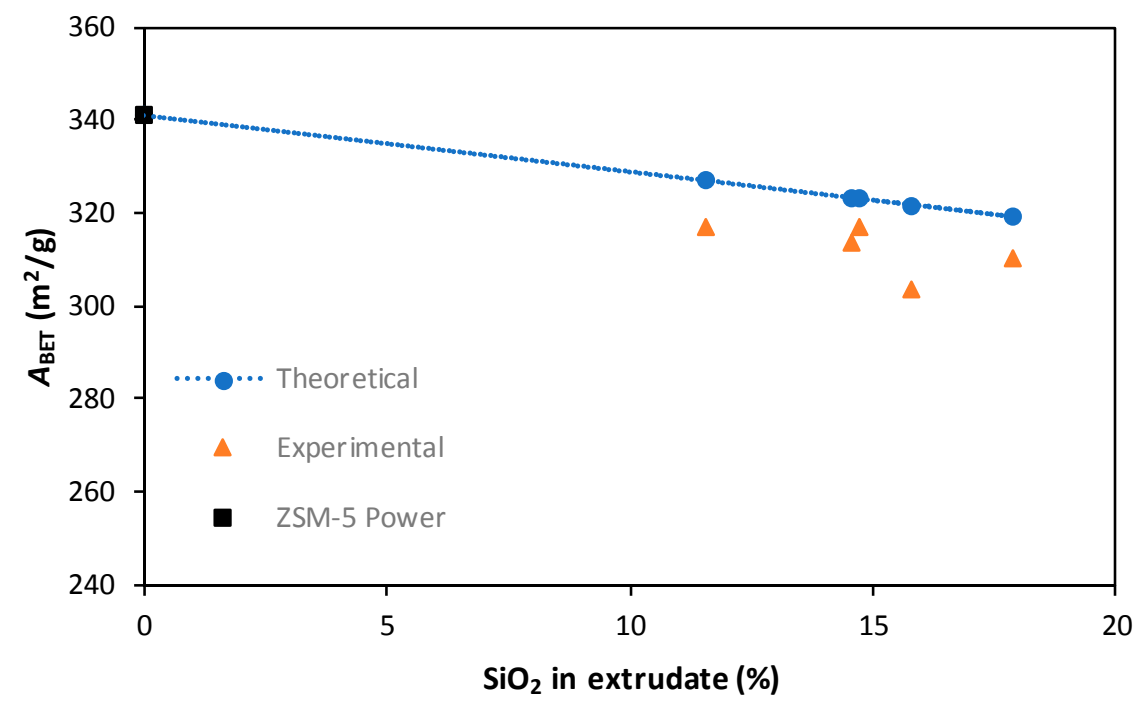

Figure 6. BET surface area as a function of the silica content in the extrudate after thermal treatment at $773 \mathrm{~K}$. The experimental data are compared with the theoretical value considering the original BET surface areas from the ZSM- 5 and the amount of $\mathrm{SiO}_{2}$ employed.

From the compression tests, SEM imaging, and $\mathrm{N}_{2}$ adsorption experiments, we can conclude that an intermediate amount of silica ( $14 \%$ as used to produce sample 5$)$ resulted in a very good quality sample with less surface rugosity and higher density. For this reason, sample 5 was used for adsorption characterization.

\subsection{Adsorption Equilibrium of $\mathrm{CH}_{4}, \mathrm{CO}_{2}$, and $\mathrm{H}_{2} \mathrm{O}$}

Figures 7 and 8 present the adsorption equilibria of $\mathrm{CH}_{4}$ and $\mathrm{CO}_{2}$ on ZSM- 5 extrudates sample 5 at 303,323 , and $343 \mathrm{~K}$ up to $100 \mathrm{kPa}$. The shape of the isotherms is Type I, and the results show that the $\mathrm{CH}_{4}$ experimental data were successfully fitted with the Langmuir model; in the case of $\mathrm{CO}_{2}$ adsorption equilibrium, the Langmuir fitting is rather poor, especially in the low-pressure region. In this case, the dual-site Langmuir (DSL) model presents very good fitting of the experimental data. The Langmuir and DSL fitting parameters are listed in Table 3 along with the model details. The results obtained for $\mathrm{CH}_{4}$ adsorption on ZSM-5 extrudates is higher than reported for Na-ZSM-5 with Si/Al $=130$ [37]. For example, at $100 \mathrm{kPa}$, the $\mathrm{CH}_{4}$ adsorption capacity of our sample is more than double ( 2.3 times) 
when compared with the lower $\mathrm{Si} / \mathrm{Al} \mathrm{Na-ZSM}-5$ sample. However, the results are comparable with other studies made with higher $\mathrm{Si} / \mathrm{Al}$ ratios, where the differences observed at $100 \mathrm{kPa}$ are smaller than $4 \%[38,39]$. The amount of $\mathrm{CO}_{2}$ is also comparable with previous data of $\mathrm{ZSM}-5$ with higher $\mathrm{Si} / \mathrm{Al}$ ratio, which is lower than in the case of more acidic samples with other cations. For example, at $90 \mathrm{kPa}$ and $303 \mathrm{~K}$, the amount of adsorbed $\mathrm{CO}_{2}$ shows a difference as low as $2 \%$ when compared with the data previously reported by Heymans et al. [39]. On the other hand, our sample shows a decrease in $\mathrm{CO}_{2}$ adsorption capacity of approximately $18 \%$ and $30 \%$ when compared with samples with lower Si/Al ratios of 130 [37] and 30 [40], respectively. Despite lower selectivity of our sample, the shape of the isotherms are more linear and, thus, the regeneration in a PSA process can be performed at a higher pressure, reducing the overall power consumption.

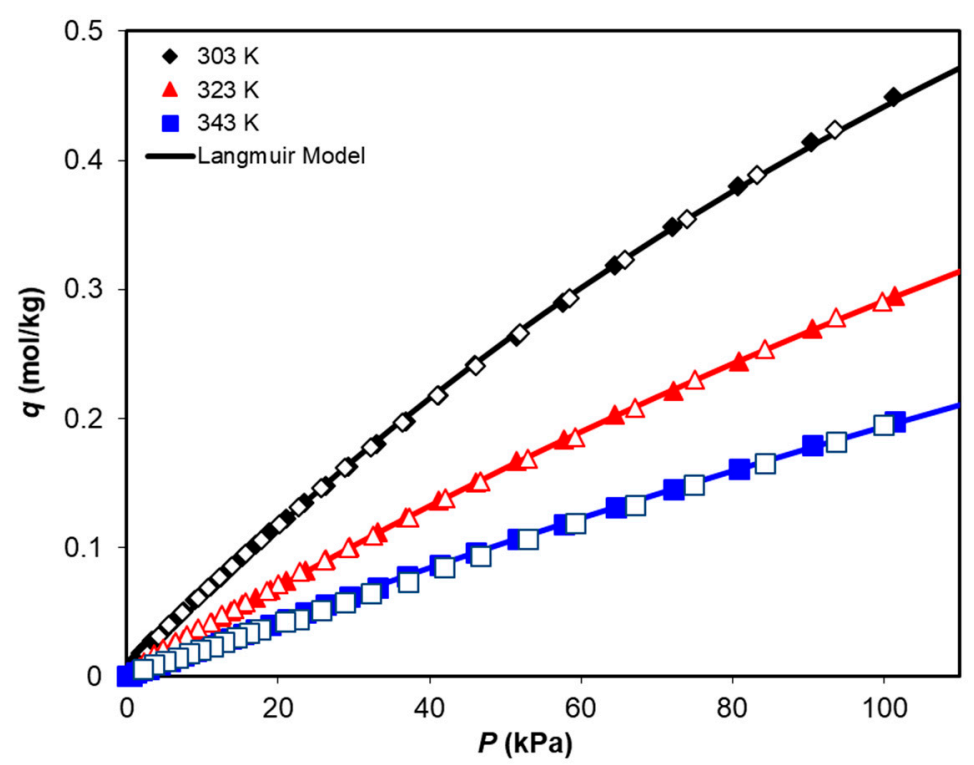

Figure 7. Adsorption equilibrium isotherms of $\mathrm{CH}_{4}$ on ZSM-5 extrudates at 303, 323, and $343 \mathrm{~K}$. The filled symbols denote adsorption data and open symbols denote desorption data. Solid lines represent Langmuir model fitting.

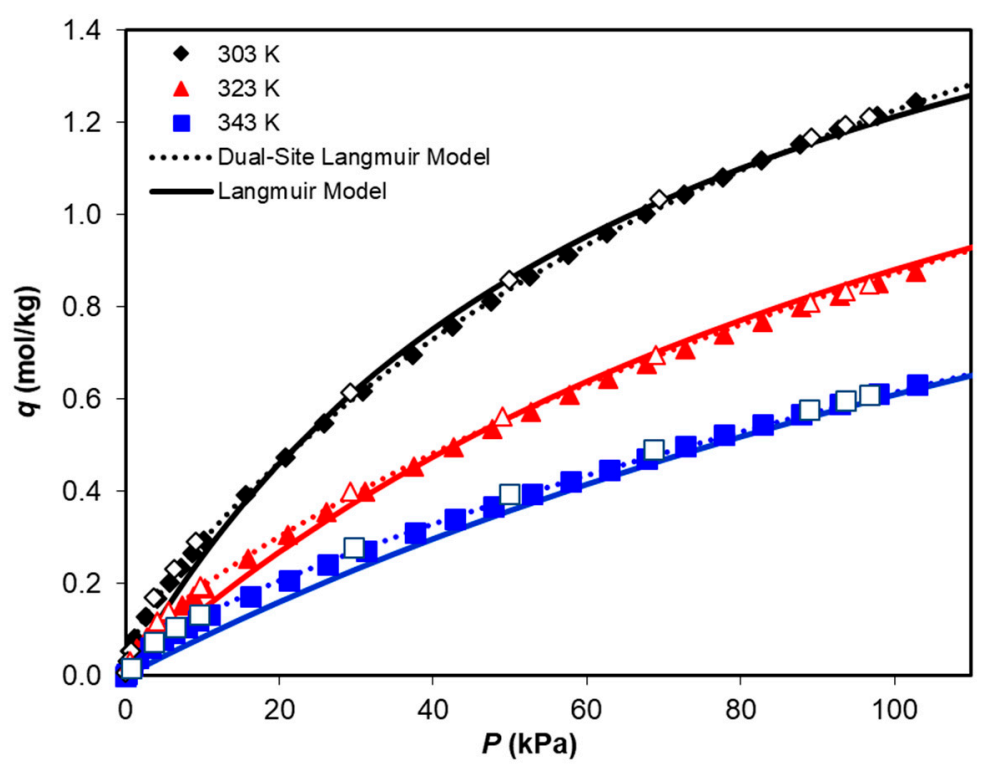

Figure 8. Adsorption equilibrium isotherms of $\mathrm{CO}_{2}$ on ZSM-5 extrudates at 303, 323, and $343 \mathrm{~K}$. The filled symbols denote adsorption data and open symbols denote desorption data. Solid and dashed lines represent the fittings obtained using the Langmuir and dual-site Langmuir models, respectively. 
Table 3. Langmuir and dual-site Langmuir fitting parameters for $\mathrm{CH}_{4}, \mathrm{CO}_{2}$, and $\mathrm{H}_{2} \mathrm{O}$ adsorption on ZSM-5 extrudates.

\begin{tabular}{|c|c|c|c|c|c|c|}
\hline \multicolumn{7}{|c|}{ Langmuir Model } \\
\hline \multicolumn{4}{|c|}{$q_{\mathrm{i}}=\frac{q_{\max , \mathrm{i}} K_{\mathrm{i}} P}{1+K_{i} P}$} & \multicolumn{3}{|c|}{$K_{\mathrm{i}}=K_{\mathrm{i}}^{0} \exp \left(\frac{-\Delta H}{R T}\right)$} \\
\hline & \multicolumn{3}{|c|}{$\mathrm{q}_{\max }(\mathrm{mol} / \mathrm{kg})$} & $K_{\mathrm{A}}^{0}\left(\mathrm{kPa}^{-1}\right)$ & \multicolumn{2}{|c|}{$-\Delta H(\mathrm{~J} / \mathrm{mol})$} \\
\hline $\mathrm{CO}_{2}$ & \multicolumn{3}{|c|}{2.04} & $3.79 \times 10^{-7}$ & \multicolumn{2}{|c|}{26,600} \\
\hline $\mathrm{CH}_{4}$ & & 1.47 & & $5.70 \times 10^{-7}$ & \multicolumn{2}{|c|}{22,500} \\
\hline \multicolumn{7}{|c|}{ Dual-Site Langmuir Model } \\
\hline \multicolumn{4}{|c|}{$q_{\mathrm{i}}=\frac{q_{\max 1, i} K_{1, i} P}{1+K_{1, i} P}+\frac{q_{\max 2, \mathrm{i}} K_{2, \mathrm{i}} P}{1+K_{2, \mathrm{i}} P}$} & \multicolumn{3}{|c|}{$K_{\mathrm{i}}=K_{\mathrm{i}}^{0} \exp \left(\frac{-\Delta H}{R T}\right)$} \\
\hline & $\mathrm{q}_{\max 1}(\mathrm{~mol} / \mathrm{kg})$ & $K_{1}^{0}\left(\mathrm{kPa}^{-1}\right)$ & $-\Delta H_{1}(\mathrm{~J} / \mathrm{mol})$ & $\mathrm{q}_{\max 2}(\mathrm{~mol} / \mathrm{kg})$ & $K_{2}^{0}\left(\mathrm{kPa}^{-1}\right)$ & $-\Delta H_{2}(\mathrm{~J} / \mathrm{mol})$ \\
\hline $\mathrm{CO}_{2}$ & 2.360 & $3.77 \times 10^{-7}$ & 25,417 & 0.106 & $1.39 \times 10^{-7}$ & 39,886 \\
\hline $\mathrm{H}_{2} \mathrm{O}$ & 0.869 & $2.55 \times 10^{-8}$ & 45,071 & 0.187 & $7.91 \times 10^{-5}$ & 37,394 \\
\hline
\end{tabular}

Figure 9 shows the isosteric heats of adsorption $\left(\mathrm{Q}_{\mathrm{st}}\right)$ for $\mathrm{CO}_{2}$ and $\mathrm{CH}_{4}$ as a function of the respective loadings. $\mathrm{Q}_{\mathrm{st}}$ has been determined directly from the experimental adsorption equilibria data, as represented in Figure 9 by the empty $\left(\mathrm{CH}_{4}\right)$ and solid symbols $\left(\mathrm{CO}_{2}\right)$, by fitting it to 6th-order polynomials and applying the integrated form of the Clapeyron equation. The study of isosteric heat confirms the occurrence of physisorption for both $\mathrm{CO}_{2}$ and $\mathrm{CH}_{4}\left(\mathrm{Q}_{\mathrm{st}}<80 \mathrm{~kJ} / \mathrm{mol}\right)$. $\mathrm{CO}_{2}$ adsorption involves higher interaction energy than $\mathrm{CH}_{4}$, although both components show variation of $Q_{\text {st }}$ with loading, indicative of energetically heterogenous behavior. The results presented in Figure 9 show that the $\Delta H$ parameter employed in the Langmuir fitting (solid lines), reported in Table 3 , is in good agreement with the calculated values of $Q_{s t}$.

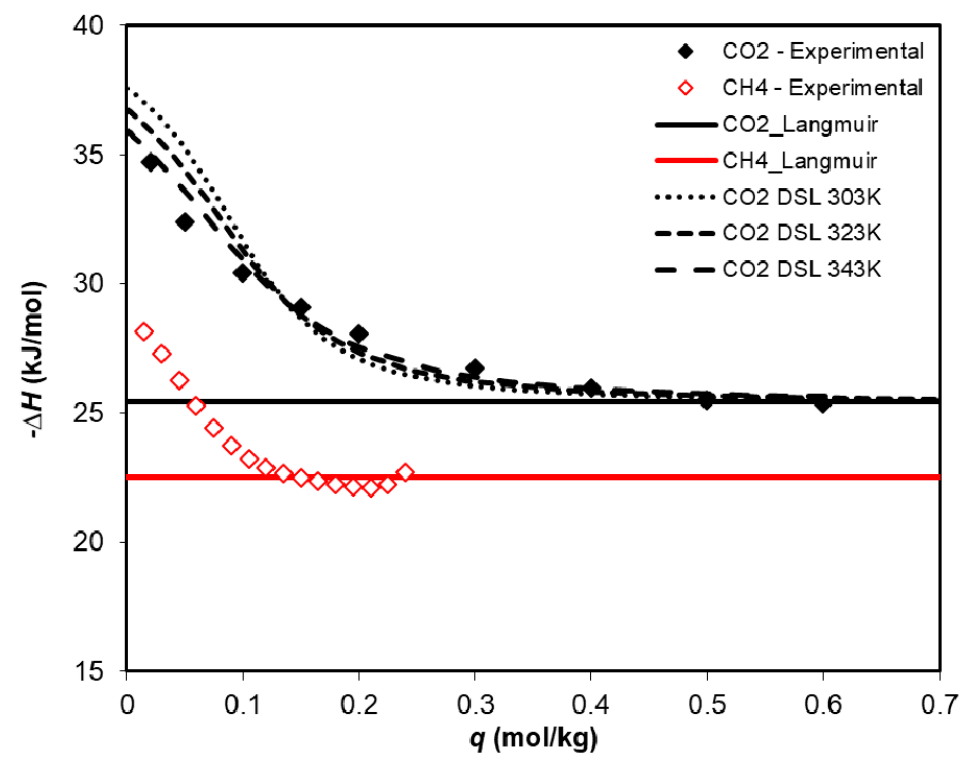

Figure 9. Isosteric heat as a function of loading for $\mathrm{CO}_{2}$ and $\mathrm{CH}_{4}$ on $\mathrm{ZSM}-5$. The closed and open symbols denote the isosteric heat calculated from the isosteric data derived from the experimental adsorption isotherms for $\mathrm{CO}_{2}$ and $\mathrm{CH}_{4}$, respectively. The solid lines represent the isosteric heat obtained from the Langmuir fitting; the dashed lines represent the values obtained with the DSL for $\mathrm{CO}_{2}$.

The pure-gas isosteric heat derived from the DSL model was determined by applying the following expression [41]:

$$
Q_{s t}=\frac{\Delta H_{1} q_{s a t, 1} K_{1}\left(1+K_{2} P\right)^{2}+\Delta H_{2} q_{s a t, 2} K_{2}\left(1+K_{1} P\right)^{2}}{q_{s a t, 1} K_{1}\left(1+K_{2} P\right)^{2}+q_{s a t, 2} K_{2}\left(1+K_{1} P\right)^{2}} .
$$


The heterogeneity consideration in the DSL model allows the obtained isosteric heat to describe, very well, the values obtained using the polynomial fitting and integrated form of the Clapeyron equation. This is observed by the good agreement between the dashed lines and the filled symbols in Figure 9. Furthermore, it is observed that $\mathrm{Q}_{\mathrm{st}}$ is mostly independent of temperature within the studied temperature range.

Figure 10 presents the $\mathrm{CO}_{2} / \mathrm{CH}_{4}$ ideal equilibrium selectivity, calculated based on data from pure gases. The study of selectivity, made by comparison of adsorption capacities of $\mathrm{CO}_{2}$ and $\mathrm{CH}_{4}$ under the same pressure and temperature, shows that the extrudates hold higher affinity to $\mathrm{CO}_{2}$ than $\mathrm{CH}_{4}$. This feature is highly pressure-dependent, decreasing significantly as the pressure increases.

Figure 11 presents the adsorption equilibria of water vapor on ZSM-5 extrudates at 303, 323, and $343 \mathrm{~K}$. The solid lines correspond to the fitting of the DSL model using the parameters reported in Table 3. The fitting with the Langmuir model was not very accurate. Previous studies report that the saturation concentration of water in ZSM-5 presents significant variation in connection with $\mathrm{Si} / \mathrm{Al}$ ratios and the presence of defects within the porous material [42,43]. For this reason, due to the high Si/Al ratio in the ZSM-5 extrudates, a significantly lower $\mathrm{H}_{2} \mathrm{O}$ uptake was obtained when compared with previously reported data [37]. For example, at $323 \mathrm{~K}$ and $1.8 \mathrm{kPa}$, our sample adsorbs less than half the amount of $\mathrm{H}_{2} \mathrm{O}$ than for the referred lower $\mathrm{Si} / \mathrm{Al}$ ratio sample. This is another advantage of having an adsorbent with high $\mathrm{Si} / \mathrm{Al}$ ratio where the co-adsorbed water will have a much smaller influence on the $\mathrm{CO}_{2} / \mathrm{CH}_{4}$ ratio and loading amounts. As an example, we present in Figure 12 the prediction of the $\mathrm{CO}_{2}$ loading in the presence of 0.2 and $1.0 \mathrm{kPa}$ of water at $303 \mathrm{~K}$ using the multicomponent extension of the DSL model. The loading of $\mathrm{CO}_{2}$ is reduced, but not as drastically as in other zeolites.

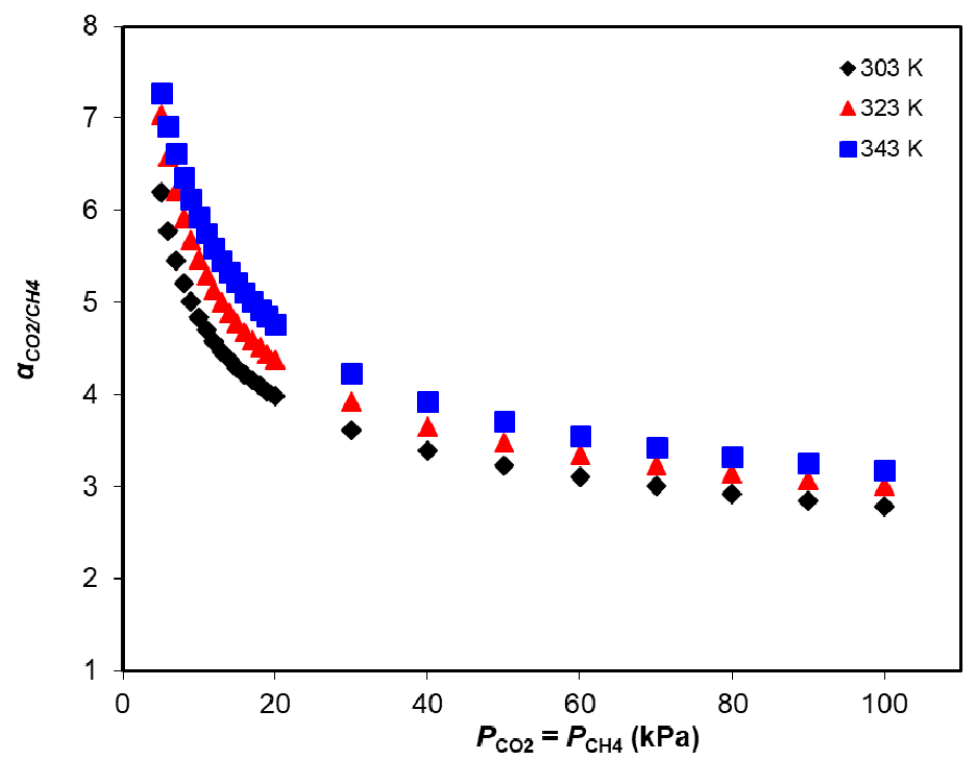

Figure 10. $\mathrm{CO}_{2} / \mathrm{CH}_{4}$ ideal selectivity as a function of the partial pressure in an equimolar mixture at $303 \mathrm{~K}(\bullet), 323 \mathrm{~K}(\boldsymbol{\bullet})$, and $343 \mathrm{~K}(\mathbf{\bullet})$. 


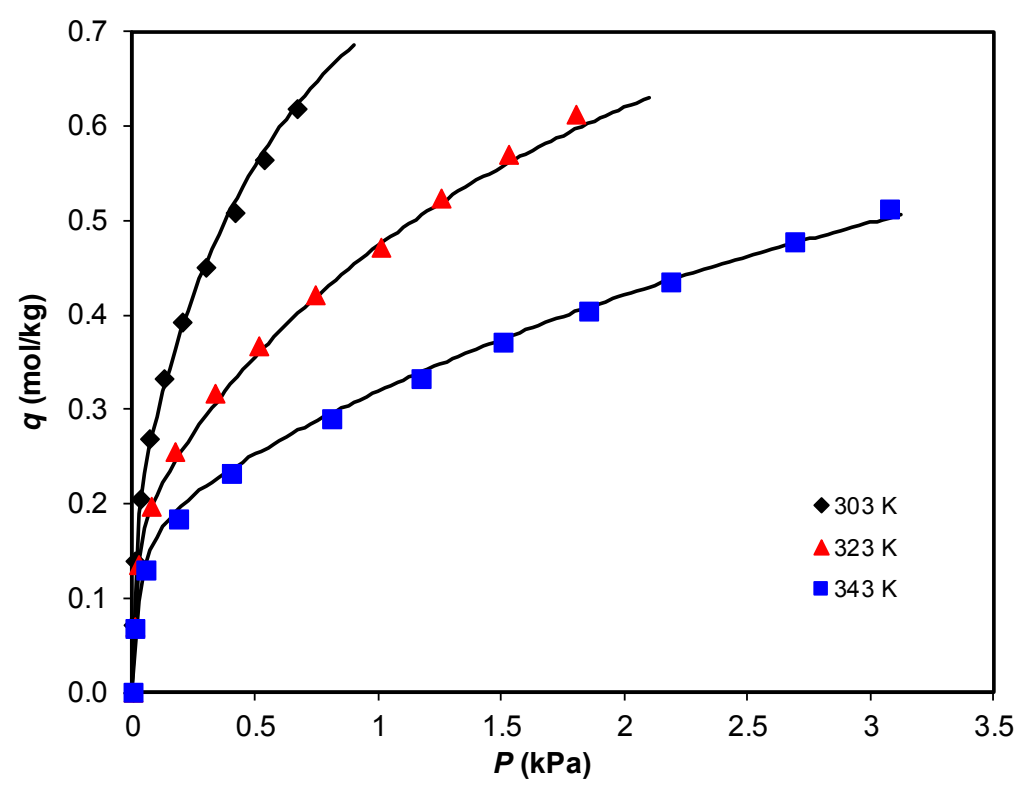

Figure 11. Adsorption equilibrium isotherms of $\mathrm{H}_{2} \mathrm{O}$ on ZSM-5 extrudates at $303 \mathrm{~K}(\bullet), 323 \mathrm{~K}(\boldsymbol{\Delta})$, and $343 \mathrm{~K}(\boldsymbol{\square})$. Solid lines represent the dual-site Langmuir model fittings.

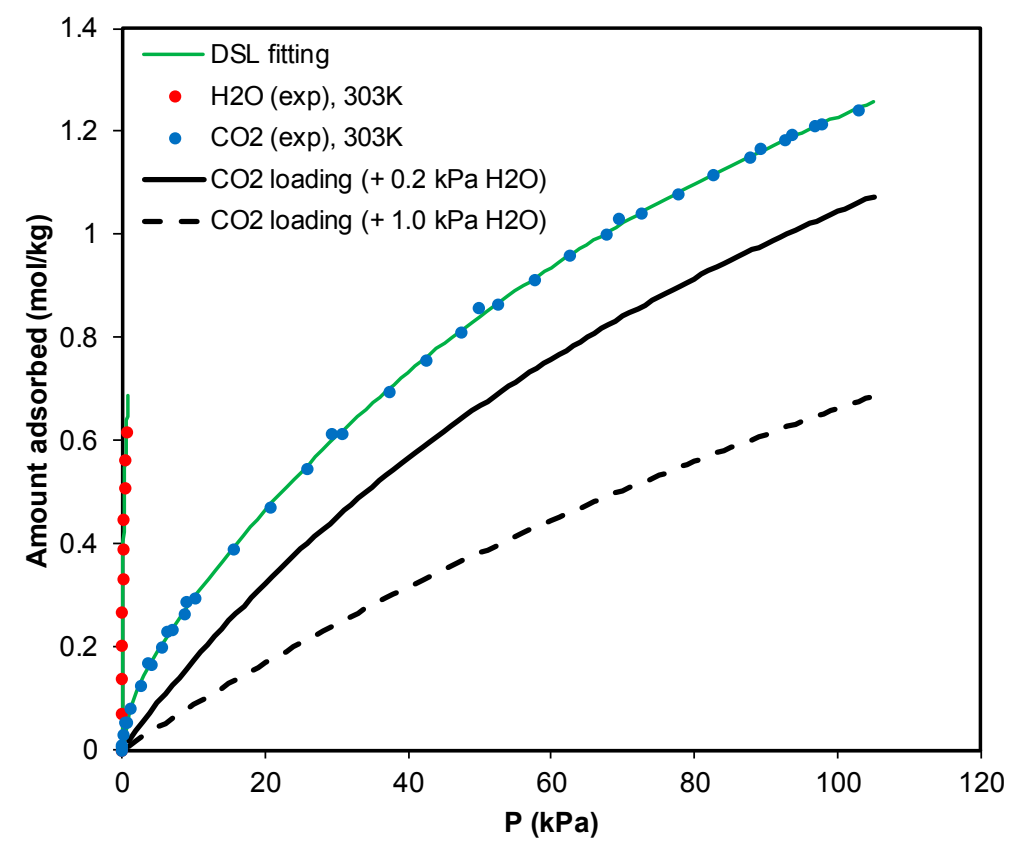

Figure 12. Adsorption equilibrium isotherms of $\mathrm{H}_{2} \mathrm{O}$ and $\mathrm{CO}_{2}$ on $\mathrm{ZSM}-5$ extrudates at $303 \mathrm{~K}$ and the prediction of multicomponent $\mathrm{CO}_{2}$ loading using 0.2 and $1.0 \mathrm{kPa}$ partial pressure of water.

\section{Conclusions}

This study has focused on the extrusion of zeolite ZSM-5 with high Si/Al ratios using silica binders to avoid zeolite denaturation during shaping. The obtained extrudates were characterized by measuring their density, surface area, scanning electron microscopy, and crushing strength. The best sample (sample 5) was selected for measurement of adsorption equilibrium of $\mathrm{CH}_{4}, \mathrm{CO}_{2}$, and $\mathrm{H}_{2} \mathrm{O}$ to evaluate the viability of the application of these materials for biogas upgrading.

Experiments were made with different amounts of silica as permanent binder and of polyvinyl alcohol (PVA) as a macroporosity generator. The optimal PVA content is approximately $5 \%$ while an amount of silica around $14 \%$ results in extrudates with higher density, good mechanical properties, low surface roughness, and low reduction of surface area. 
The best sample of produced extrudates was also characterized in terms of adsorption equilibrium of $\mathrm{CO}_{2}, \mathrm{CH}_{4}$, and $\mathrm{H}_{2} \mathrm{O}$. Its high silica ratio resulted in an apparent lower $\mathrm{CO}_{2} / \mathrm{CH}_{4}$ selectivity when compared with other data available in the literature. However, the adsorption isotherms were less steep, which is reflected in the lower heat of adsorption. Also important is the very small amount of water that is adsorbed by our sample. This means that the adsorbent can still be selective to $\mathrm{CO}_{2}$ in the presence of a considerable amount of humidity in the gas to be treated.

The prepared extrudates maintain a high $\mathrm{Si} / \mathrm{Al}$ and have surface area reduction as low as $7 \%$ and good mechanical properties. The linearity of their $\mathrm{CO}_{2}$ adsorption isotherms makes the ZSM-5 extrudates with high $\mathrm{Si} / \mathrm{Al}$ ratio an interesting material to be used in adsorption processes for biogas upgrading in which $\mathrm{CO}_{2}$ can be desorbed without using very low vacuum.

Author Contributions: All authors contributed to the manuscript and have read and agreed to the published version of the manuscript.

Funding: We acknowledge the support of the Research Council of Norway through the CLIMIT program by the SINTERCAP project (233818). This publication has been produced with partial support from the BIGCCS Centre, performed under the Norwegian research program Centres for Environment-friendly Energy Research (FME).

Acknowledgments: The author acknowledges the following partners for their contributions: ConocoPhillips, Gassco, Shell, Statoil, TOTAL, GDF SUEZ and the Research Council of Norway (193816/S60). Rui P. P. L. Ribeiro acknowledges FCT/MCTES for financial support through grant SFRH/BPD/103533/2014 and the Norma Transitória DL57/2016 Program Contract. This work was partially supported by the Associate Laboratory for Green Chemistry - LAQV which is financed by national funds from FCT/MCTES (UID/QUI/50006/2019).

Conflicts of Interest: The authors declare no conflicts of interest. The funders had no role in the design of the study; in the collection, analyses, or interpretation of data; in the writing of the manuscript, or in the decision to publish the results.

\section{References}

1. Ruthven, D.M. Principles of Adsorption and Adsorption Processes; Wiley-Interscience: New York, NY, USA, 1984.

2. Yang, R.T. Gas Separation by Adsorption Processes; Butterworth Publishers: Boston, MA, USA, 1987.

3. Perego, C.; Villa, P. Catalyst preparation methods. Catal. Today 1997, 34, 281-305. [CrossRef]

4. Masala, A.; Vitillo, J.G.; Mondino, G.; Martra, G.; Blom, R.; Grande, C.A.; Bordiga, S. Conductive ZSM-5-Based Adsorbent for CO2 Capture: Active Phase vs Monolith. Ind. Eng. Chem. Res. 2017, 56, 8485-8498. [CrossRef]

5. Omojola, T.; Cherkasov, N.; Rebrov, E.V.; Lukyanov, D.B.; Perera, S.P. Zeolite minilith: A unique structured catalyst for the methanol to gasoline process. Chem. Eng. Process. 2018, 131, 137-143. [CrossRef]

6. Armor, J.N.; Farris, T.S. Simultaneous exchange and extrusion of metal exchanged zeolites. Appl. Catal. A 1994, 114, L187-L190. [CrossRef]

7. Schwarz, S.; Kojima, M.; O'Connor, C.T. Effect of stirring, extrusion and pelletisation on high pressure propene oligomerisation and xylene isomerisation over ZSM-5. Appl. Catal. 1991, 68, 81-96. [CrossRef]

8. Grande, C.A.; Kvamsdal, H.; Mondino, G.; Blom, R. Development of Moving Bed Temperature Swing Adsorption (MBTSA) Process for Post-combustion CO2 Capture: Initial Benchmarking in a NGCC Context. Energy Procedia 2017, 114, 2203-2210. [CrossRef]

9. Hou, J.; Sapnik, A.F.; Bennett, T.D. Metal-organic framework gels and monoliths. Chem. Sci. 2020, 11, 310-323. [CrossRef]

10. Kusgens, P.; Zgaverdea, A.; Fritz, H.G.; Siegle, S.; Kaskel, S. Metal-Organic Frameworks in Monolithic Structures. J. Am. Ceram. Soc. 2010, 93, 2476-2479. [CrossRef]

11. Grande, C.A.; Águeda, V.I.; Spjelkavik, A.; Blom, R. An efficient recipe for formulation of metal-organic Frameworks. Chem. Eng. Sci. 2015, 124, 154-158. [CrossRef]

12. Hong, W.Y.; Perera, S.P.; Burrows, A.D. Manufacturing of metal-organic framework monoliths and their application in CO2 adsorption. Microporous Mesoporous Mater. 2015, 214, 149-155. [CrossRef]

13. Wu, D.; Tang, M. Effects of process factors on extrusion of hierarchically porous ZSM-5 zeolite. Powder Technol. 2019, 352, 79-90. [CrossRef]

14. Wang, Y.; Chang, Y.; Liu, M.; Zhang, A.; Guo, X. A facile strategy to prepare shaped ZSM-5 catalysts with enhanced para-xylene selectivity and stability for toluene methylation: The effect of in situ modification by attapulgite. Molecules 2019, 24, 3462. [CrossRef] [PubMed] 
15. Hernando, H.; Ochoa-Fernandez, C.; Shamzhy, M.; Moreno, I.; Fermoso, J.; Pizarro, P.; Coronado, J.M.; Cejka, J.; Serrano, D.P. The crucial role of clay binders in the performance of ZSM-5 based materials for biomass catalytic pyrolysis. Catal. Sci. Technol. 2019, 9, 789-802. [CrossRef]

16. Delgado, J.A.; Águeda, V.I.; Uguina, M.A.; Brea, P.; Grande, C.A. Comparison and evaluation of agglomerated MOFs in biohydrogen purification by means of pressure swing adsorption (PSA). Chem. Eng. J. 2017, 326, 117-129. [CrossRef]

17. Zhang, H.P.; Li, W.; Xiao, W.D. Attrition Resistant Catalyst of Direct Dimethyl Ether Synthesis. Appl. Mech. Mater. 2012, 174, 97-101. [CrossRef]

18. Marigo, M.; Cairns, D.L.; Bowen, J.; Ingram, A.; Stitt, E.H. Relationship between single and bulk mechanical properties for zeolite ZSM5 spray-dried particles. Particuology 2014, 14, 130-138. [CrossRef]

19. Chaemchuen, S.; Zhou, K.; Mousavi, B.; Ghadamyari, M.; Heynderickx, P.M.; Zhuiykov, S.; Yusubov, M.S.; Verpoort, F. Spray drying of zeolitic imidazolate frameworks: Investigation of crystal formation and properties. CrystEngComm 2018, 20, 3601-3608. [CrossRef]

20. Spjelkavik, A.I.; Aarti Divekar, S.; Didriksen, T.; Blom, R. Forming MOFs into Spheres by Use of Molecular Gastronomy Methods. Chem. Eur. J. 2014, 20, 8973-8978. [CrossRef]

21. Lee, D.W.; Didriksen, R.; Olsbye, U.; Blom, R.; Grande, C.A. Shaping of metal-organic framework UiO-66 using alginates: Effect of operation variables. Sep. Purif. Technol. 2020, 235, 116182. [CrossRef]

22. Finsy, V.; Ma, L.; Alaerts, L.; De Vos, D.E.; Baron, G.V.; Denayer, J.F.M. Separation of CO2/CH4 Mixtures with the MIL-53(Al) Metal-Organic Framework. Microporous Mesoporous Mater. 2009, 120, 221-227. [CrossRef]

23. Peterson, G.W.; DeCoste, J.B.; Glover, T.G.; Huang, Y.; Jasuja, H.; Walton, K.S. Effects of pelletization pressure on the physical and chemical properties of the metal-organic frameworks Cu3(BTC)2 and UiO-66. Microporous Mesoporous Mater. 2013, 179, 48-53. [CrossRef]

24. Ribeiro, R.P.P.L.; Antunes, C.L.; Garate, A.U.; Portela, A.F.; Plaza, M.G.; Mota, J.P.B.; Esteves, I.A.A.C. Binderless shaped metal-organic framework particles: Impact on carbon dioxide adsorption. Microporous Mesoporous Mater. 2019, 275, 111-121. [CrossRef]

25. Nayak, N.; Vitorino, N.; Frade, J.R.; Kovalevsky, A.V.; Alves, V.D.; Crespo, J.G.; Portugal, C.A.M. Design of alumina monoliths by emulsion-gel casting: Understanding the monolith structure from a rheological approach. Mater. Des. 2018, 157, 119-129. [CrossRef]

26. Lefevere, J.; Protasova, L.; Mullens, S.; Meynen, V. 3D-printing of hierarchical porous ZSM-5: The importance of the binder system. Mater. Des. 2017, 134, 331-341. [CrossRef]

27. Lefevere, J.; Mullens, S.; Meynen, V. The impact of formulation and 3D-printing on the catalytic properties of ZSM-5 zeolite. Chem. Eng. J. 2018, 349, 260-268. [CrossRef]

28. Couck, S.; Cousin-Saint-Remi, J.; Van der Perre, S.; Baron, G.V.; Minas, C.; Ruch, P.; Denayer, J.F.M. 3D-printed SAPO-34 monoliths for gas separation. Microporous Mesoporous Mater. 2018, 255, 185-191. [CrossRef]

29. Lind, A.; Vistad, Ø.; Sunding, M.F.; Andreassen, K.A.; Cavka, J.H.; Grande, C.A. Multi-purpose structured catalysts designed and manufactured by 3D printing. Mater. Des. 2020, 187, 108377. [CrossRef]

30. Akhtar, F.; Andersson, L.; Ogunwumi, S.; Hedin, N.; Bergström, L. Structuring Adsorbents and Catalysts by Processing of Porous Powders. J. Eur. Ceram. Soc. 2014, 34, 1643-1666. [CrossRef]

31. DeLuca, J.P.; Campbell, L.E. Monolithic Catalyst Supports. In Advanced Materials in Catalysis; Burton, J.J., Garten, R.L., Eds.; Academic Press: New York, NY, USA, 1977; pp. 293-324.

32. Shams, K.; Mirmohammadi, S.J. Preparation of 5A zeolite monolith granular extrudates using kaolin: Investigation of the effect of binder on sieving/adsorption properties using a mixture of linear and branched paraffin hydrocarbons. Microporous Mesoporous Mater. 2007, 106, 268-277. [CrossRef]

33. Calleja, G.; Pau, J.; Calles, J.A. Pure and Multicomponent Adsorption Equilibrium of Carbon Dioxide, Ethylene, and Propane on ZSM-5 Zeolites with Different Si/Al Ratios, J. Chem. Eng. Data 1998, 43, 994-1003. [CrossRef]

34. Talesh, S.S.A.; Fatemi, S.; Hashemi, S.J.; Ghasemi, M. Effect of Si/Al Ratio on CO2-CH4 Adsorption and Selectivity in Synthesized SAPO-34. Sep. Sci. Technol. 2010, 45, 1295-1301. [CrossRef]

35. Sarti, E.; Chenet, T.; Pasti, L.; Cavazzini, A.; Rodeghero, E.; Martucci, A. Effect of Silica Alumina Ratio and Thermal Treatment of Beta Zeolites on the Adsorption of Toluene from Aqueous Solutions. Minerals 2017, 7 , 22. [CrossRef]

36. Grande, C.A.; Cavenati, S.; Barcia, P.; Hammer, J.; Fritz, H.G.; Rodrigues, A.E. Adsorption of Propane and Propylene in Zeolite 4A Honeycomb Monolith. Chem. Eng. Sci. 2006, 61, 3053-3067. [CrossRef] 
37. Ohlin, L.; Bazin, P.; Thibault-Starzyk, F.; Hedlund, J.; Grahn, M. Adsorption of CO2, CH4, and H2O in Zeolite ZSM-5 Studied Using In Situ ATR-FTIR Spectroscopy. J. Phys. Chem. C 2013, 117, 16972-16982. [CrossRef]

38. Grande, C.A.; Mondino, G.; Lind, A.; Vistad, Ø.; Akporiaye, D. Selective Removal of CH4 from CH4/CO/H2 Mixtures. In Small-Scale Gas to Liquid Fuel Synthesis; Kanellopoulos, N., Ed.; CRC Press: Boca Raton, FL, USA, 2015.

39. Heymans, N.; Alban, B.; Moreau, S.; De Weireld, G. Experimental and theoretical study of the adsorption of pure molecules and binary systems containing methane, carbon monoxide, carbon dioxide and nitrogen. Application to the syngas generation. Chem. Eng. Sci. 2011, 66, 3850-3858. [CrossRef]

40. Dunne, J.A.; Rao, M.; Sircar, S.; Gorte, R.J.; Myers, A.L. Calorimetric heats of adsorption and adsorption isotherms 2. O2, N2, Ar, CO2, CH4, C2H6 and SF6 on NaX, H-ZSM-5 and Na-ZSM-5 zeolites. Langmuir 1996, 12, 5896-5904. [CrossRef]

41. Mathias, P.M.; Kumar, R.; Moyer, J.D.; Schork, J.M.; Srinivasan, S.R.; Auvil, S.R.; Talu, O. Correlation of Multicomponent Gas Adsorption by the Dual-Site Langmuir Model. Application to Nitrogen/Oxygen Adsorption on 5A-Zeolite. Ind. Eng. Chem. Res. 1996, 35, 2477-2483. [CrossRef]

42. Olson, D.H.; Haag, W.O.; Borghard, W.S. Use of water as a probe of zeolitic properties: Interaction of water with HZSM-5. Microporous Mesoporous Mater. 2000, 35, 435-446. [CrossRef]

43. Bolis, V.; Busco, C.; Ugliengo, P. Thermodynamic Study of Water Adsorption in High-Silica Zeolites. J. Phys. Chem. B 2006, 110, 14849-14859. [CrossRef]

(C) 2020 by the authors. Licensee MDPI, Basel, Switzerland. This article is an open access article distributed under the terms and conditions of the Creative Commons Attribution (CC BY) license (http://creativecommons.org/licenses/by/4.0/). 